\title{
Monoclonal antibodies as immune modulators for cancer therapy
}

\author{
ROBERT O DILLMAN, MD, FACP
}

\begin{abstract}
RO Dillman. Monoclonal antibodies as immune modulators for cancer therapy. Can J Infect Dis 1992;3(Suppl B):20B-25B. Monoclonal antibodies may modulate immune and/or biological responses alone, or as carriers of specific agents. Monoclonal antibodies directed against tumours may be indirectly cytotoxic by modulation of antibody-dependent, cell-mediated cytotoxicity or complement-mediated cytotoxicity. Monoclonal antibodies directed against certain tumour cell receptors may alter the biological behaviour of tumour cells such as blocking or downregulation of growth factors essential to tumour cell proliferation. Monoclonal antibodies directed to certain receptors on host immune cells, such as the CD3 receptor on Tlymphocytes, may activate those cells and increase their cytotoxicity. Antitumour monoclonal antibodies can serve as carriers of interferons, interleukin-2, tumour necrosis factor and other lymphokines and cytokines to modulate selectively the cytotoxic potential of immune cells in the vicinity of tumour cells. Cytotoxic chemotherapy agents conjugated to antitumour monoclonal antibodies may be processed differently so that they bypass certain mechanisms of drug resistance. The penultimate application of monoclonal antibodies in cancer therapy is to combine various monoclonal antibodies and immunoconjugates for selective combination therapy based on known antigenic tumour cell determinants and the status of the host immune system.
\end{abstract}

Key Words: Biotherapy, Cancer, Immunotherapy, Monoclonal antibodies

\section{Propriétés immunomodulatrices des anticorps monoclonaux utilisés en cancérologie}

RESUME: Les anticorps monoclonaux pourraient moduler les réponses immunes et/ou biologiques, seuls ou comme porteurs d'agents spécifiques. Les anticorps monoclonaux qui ciblent les tumeurs pourraient être indirectement cytotoxiques en modulant la cytotoxicité qui dépend des anticorps, qui est à médiation cellulaire ou sous la dépendance du complément. Les anticorps monoclonaux dirigés contre certains récepteurs des cellules tumorales pourraient modifier le comportement biologique de ces cellules en bloquant ou en diminuant les facteurs de croissance essentiels à la prolifération tumorale. Les anticorps monoclonaux dirigés contre certains récepteurs des cellules immunes de l'hôte, tel le récepteur CD3 des lymphocytes T, pourraient activer ces cellules et majorer leur cytotoxicitê. Les anticorps monoclonaux antitumoraux peuvent servir à transporter les interférons, l'interleukine-2, le facteur de nécrose tumorale et les autres lymphokines et cytokines, pour moduler sélectivement le potentiel cytotoxique des cellules immunes qui se trouvent à proximité des cellules tumorales. Les agents utilisés en chimiothérapie cytotoxique, associés aux anticorps antinéoplastiques, sont peut-être traités différemment et pourraient ainsi contourner certains mécanismes de pharmacorésistance. L'application la plus poussée des anticorps monoclonaux utilisés dans la lutte anticancéreuse consiste à combiner divers anticorps monoclonaux et immunoconjugués pour administrer un traitement sêlectif fondé sur les déterminants antigéniques des cellules tumorales et l'état du système immunitaire de l'hôte.

Medical Director, Hoag Cancer Center, Clinical Professor of Medicine, University of California, Irvine, California

Correspondence and reprints: Dr Robert O Dillman, Medical Director, Hoag Cancer Center, Hoag Memorial Hospital Presbyterian. 301 Newport Boulevard, Newport Beach, CA 92663 USA. Telephone (714) 760-2091, Fax (714) 760-2102 
T WO MAJOR LIMITATIONS TO EXISTING CANCER THERAPY are the lack of specificity of systemic modalities and the intra- and interpatient heterogeneity of cancer cells. Because of their natural specificity, antibodies against tumour-specific or associated antigens could be useful in overcoming these obstacles (1). In 1975, Kohler and Milstein (2) described the secretion of a monoclonal antibody by a B cell hybridoma. Subsequently, biotechnology companies have produced sufficient quantities of monoclonal antibodies for clinical investigation. Approaches for their use in cancer therapy are summarized below.

\section{MONOCLONAL ANTIBODY ALONE}

Indirect cytotoxicity: Some monoclonal antibodies fix complement or interact with cytolytic and phagocytic cells to eliminate cells which are recognized by distinct surface molecules called antigens. Complement-dependent cytotoxicity (CDC) involves fixation of complement to the Fc portion of the immunoglobulin (Ig) molecule followed by activation of the complement cascade and the enzymatic puncturing of the tumour cell membrane resulting in cell death. Certain 'effector cells' such as monocytes, macrophages, granulocytes and certain lymphocytes have Fc receptors which bind to the Fc portion of Ig molecules. Cell killing via this combination is called antibody-dependent, cell-mediated cytotoxicity (ADCC). Monoclonal antibodies can bind to tumour cells and subsequently effector cells attach to the exposed Fc. Alternatively, injected monoclonal antibodies may attach to circulating effector cells and subsequently bind to tumour cells. Once such cells come in contact with tumour cells, they destroy tumour cell membranes enzymatically.
For interaction with human complement, murine IgM is most efficient in CDC followed by the $\mathrm{IgG}_{3}$ subclass, while $\operatorname{IgG}_{2 A}$, IgG $\operatorname{Ig}_{1}$ and $\operatorname{IgG}_{2 B}$ murine antibodies are generally ineffective. For ADCC with murine monoclonal antibodies and human effector cells, the best results are obtained with murine subclasses $\operatorname{IgG}_{2 \mathrm{~A}}$ and IgG $_{3}$. This correlates with the binding affinities of the $\mathrm{Fc}$ receptors for Ig molecules and the number of antigen-binding sites. For human antibodies and mouse-human chimeric antibodies, the best results in CDC are obtained with $\operatorname{IgM}>\mathrm{IgG}_{1}>\mathrm{IgG}_{3}>\mathrm{IgG}_{2}>$ $\mathrm{IgG}_{4}$, while for ADCC this may be confined to human $\operatorname{IgG}_{1}$ and $\mathrm{IgG}_{3}$ monoclonal antibodies.

Direct effects: Monoclonal antibodies may be directly cytotoxic, or impair tumour cell proliferation by inhibiting growth factors. They could also function indirectly with other components of the immune system as described above.

Tumour cells express increased numbers of receptors for molecules which augment their proliferation; many of these receptors are the products of oncogenes. Monoclonal antibodies directed against these receptors may compete with growth factors and/or downregulate receptors so that proliferative effects are lost. Much work in this area has focused on monoclonal antibodies directed against receptors for transferrin, interleukin-2 and epidermal growth factor.

B lymphocytes express the idiotype of their secretory Ig on their surface; idiotype is important in the activation and regulation of $\mathrm{B}$ cell proliferation. According to the 'network hypothesis', an anti-idiotype monoclonal antibody could inhibit proliferation of an aberrant B cell clone (3). This could be applied to therapy of B lymphocyte malignancies.

TABLE 1

Published trials of monoclonal antibody passive therapy in hematopoietic malignancies

\begin{tabular}{|c|c|c|c|c|}
\hline Monoclonal antibody & Immunoglobulin & Disease & Author & Response rate \\
\hline Several & Mu lgM & AML & Ball & $0 / 3$ \\
\hline J-5 (CALLA) & Mu lgGl & ALL & Ritz & $0 / 4$ \\
\hline Leu-1 (CD-5) & $\mathrm{Mu} \lg \mathrm{G}_{2 \mathrm{~A}}$ & T-cell ALL & Levy & $0 / 8$ \\
\hline Anti-TAC & $\mathrm{Mu} \lg \mathrm{G}_{2 \mathrm{~A}}$ & T-ALL & Waldmann & $2 / 9$ \\
\hline T101 (CD5) & $\mathrm{Mu} \lg \mathrm{G}_{2 \mathrm{~A}}$ & CLL & Dillman & $0 / 6$ \\
\hline T101 (CD5) & Mu $\lg G_{2 A}$ & CLL & Foon & $0 / 13$ \\
\hline Anti-idiotype & Mu lgG & Lymphoma & Rankin & $0 / 2$ \\
\hline IF5 (CD20) & $\mathrm{Mu} \lg \mathrm{G}_{2 \mathrm{~A}}$ & Lymphoma & Press & $1 / 4$ \\
\hline Anti-idiotype & Ch lgG। & Lymphoma & Hamblin & $0 / 1$ \\
\hline Leu-1 (CD5) & $\mathrm{Mu} \lg \mathrm{G}_{2 \mathrm{~A}}$ & $\mathrm{CTCL}$ & Miller & $4 / 7$ \\
\hline T101 (CD5) & $\mathrm{Mu} \lg \mathrm{G}_{2 \mathrm{~A}}$ & CTCL & Dillman & $0 / 10$ \\
\hline
\end{tabular}


TABLE 2

Published trials of monoclonal antibody passive therapy in solid tumours

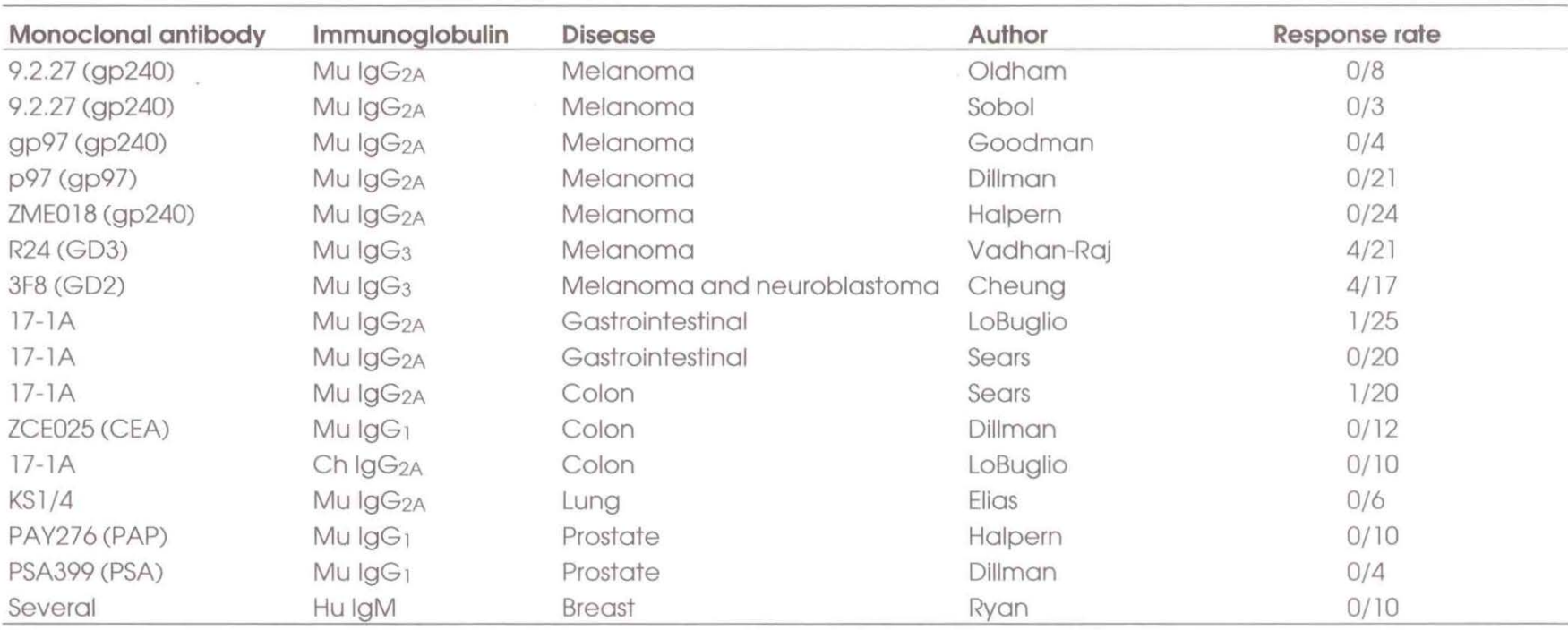

Ch Chimeric; Hu Human; Mu Murine

Immunization: Injection of murine monoclonal antibodies $\left(\mathrm{AB}_{1}\right)$ into humans results in production of human antimouse antibodies $\left(\mathrm{AB}_{2}\right)$ and, with repeated exposure, much of this is directed against the idiotype or hypervariable region of the mouse Ig. This human anti-idiotype antibody $\left(\mathrm{AB}_{2}\right)$, in turn, induces an antiidiotype $\left(\mathrm{AB}_{3}\right)$ response to the human antimouse antibody. Sometimes the $\mathrm{AB}_{3}$ is the mirror image of the murine monoclonal antibody which was originally injected. An antibody $\left(\mathrm{AB}_{2}\right)$ can be raised against the idiotype of a murine antibody $\left(A B_{1}\right)$ which reacts with tumour-associated antigen (4). A patient immunized with $\mathrm{AB}_{2}$ may produce an $\mathrm{AB}_{3}$ which reacts with the desired tumour antigen with the same reactivity as $A_{1}$, except it would be a human antibody produced endogenously. This approach is similar to immunizing with tumour antigen except the idiotype may be more immunogenic.

\section{CLINICAL TRIALS}

Murine monoclonal antibodies have been used alone in hematopoietic malignancies (Table 1) and in patients with solid tumours (Table 2). In clinical trials with murine IgG $_{2}$ and IgG $_{1}$ monoclonal antibodies, durable antitumour effects have seldom been seen, and complete responses have been exceedingly rare. With the exception of chronic lymphocytic leukemia and perhaps some B cell lymphoma patients, virtually all individuals exposed to murine monoclonal antibodies have developed an antimouse immune response, typically within two weeks, which greatly alters antibody pharmacokinetics and the effects of repeated monoclonal antibody therapy.

Toxicities and side effects related to monoclonal antibody infusions have not been a significant problem (Table 3). Binding to circulating cells results in a rapid cytopenia associated with fever, sweats and chills. In the absence of reactivity with circulating cells or circulating antigen, high doses of murine monoclonal antibodies have been given rapidly without side effects. However, cross-reactivity with normal tissues has resulted in antigen-specific toxicity.

Immunoreactive antibody circulates for days to weeks depending on dose, human antimouse antibodies and tumour antigen burden. The degree of antibody concentration and binding in tumour increases over time and is dose-related. Circulating antigen does compete with tumour-bound antigen for antibody binding, but antigen in the circulation can be overcome by giving larger doses of monoclonal antibodies. However, immune complexes can form and are occasionally associated with significant toxicity. This has greatly limited the application of anti-idiotype monoclonal antibodies. Very large doses (grams) of monoclonal antibody may be needed in some situations.

\section{TABLE 3}

Summary of side effects and toxicities associated with murine monocolonal antibody infusions*

\begin{tabular}{lcc}
\hline Toxicity & $\begin{array}{c}\text { Percentage of } \\
\text { patients }\end{array}$ & $\begin{array}{c}\text { Percentage of } \\
\text { infusions }\end{array}$ \\
\hline Fever & 15 & 12 \\
Transaminasemia & 14 & 8 \\
Rigors/chills & 13 & 10 \\
Diaphoresis & 10 & 10 \\
Pruritus & 9 & 9 \\
Nausea & 4 & 8 \\
Emesis & 3 & 2 \\
Hypotension & 2 & 1 \\
Bronchospasm & 2 & 1 \\
Anaphylaxis & $<1$ & $<1$
\end{tabular}

"For 291 infusions in 177 patients, 20 difference malignancies, 19 murine and three human monoclonal antibodies (5) 
Immunoconjugates: Radioisotopes, natural toxins, chemotherapy agents or other substances or cells can be chemically linked to monoclonal antibodies to form 'immunoconjugates'. There are several issues critical for any immunoconjugate. First is successful conjugation of as many cytotoxic molecules as possible (high specific activity) with retention of monoclonal antibody immunoreactivity and toxin cytotoxicity. Relative specificity for tumour is crucial. For certain toxins and drug conjugates, excellent in vitro specificity can be demonstrated despite many hours of exposure. Intracellular bioavailability is crucial for such conjugates because they must get into certain intracellular compartments for a cytotoxic effect.

Radiolabelled monoclonal antibodies: The easiest immunoconjugates to make are radiolabelled antibodies which hold promise for radioimmunodetection and radioimmunotherapy (6). The ideal energy for gamma camera imaging efficiency is between 100 and $200 \mathrm{KeV}$. The half-lives of some commonly used isotopes are 13 $\mathrm{h}$ for ${ }^{123}$ iodine, $67 \mathrm{~h}$ for ${ }^{11}{ }^{1}$ indium, $6 \mathrm{~h}$ for ${ }^{99}$ technetium and eight days for ${ }^{131}$ iodine. Technetium has superior imaging qualities, but its short half-life is a disadvantage for monoclonal antibodies which concentrate in tumour cells over time. Indium has good imaging qualities, but is difficult to conjugate chemically to monoclonal antibodies, is expensive, and in free form it concentrates in the reticuloendothelial system. ${ }^{131}$ iodine produces beta rays which could be useful for therapy, but are not helpful for imaging. ${ }^{123}$ Iodine is not widely available, has a short half-life and is relatively expensive. Radiolabelled antibodies have detected tumour which is not detectable by standard radiological diagnostic techniques.

There still is controversy regarding the advantages and disadvantages of the various alpha, beta and gamma emitters for radioimmunotherapy. Isotopes such as ${ }^{188}$ rhenium, ${ }^{90}$ yttrium and ${ }^{131}$ iodine release particles which penetrate several millimetres and, therefore, could be of value for antigen-negative cells. Alpha emitters such as ${ }^{211}$ astatine and ${ }^{212}$ bismuth are more powerful, but their energy dissipates over such a short range that killing would be limited to a single cell. Some radioimmunotherapy trials are summarized in Table 4. Therapy is hampered by prolonged circulation of radiolabelled monoclonal antibody which results in significant total body irradiation. Consequently, bone marrow suppression has been a major limitation to therapeutic intensity, while human antimouse antibodies (HAMA) have limited repeated therapy.

Immunotoxins: Potent toxins linked to antibodies are called immunotoxins. Toxicity is conveyed by whole toxins or subunits of natural substances such as ricin, abrin, modeccine, pokeweed antiviral protein, gelonin, saporin, diphtheria toxin and Pseudomonas exotoxin (7). Many of these consist of two protein chains, a B-chain which enables cell binding and an A-chain
TABLE 4

Radioimmunotherapy

\begin{tabular}{|c|c|c|}
\hline Year & First author & Results \\
\hline 1980 & Order & $\begin{array}{l}\text { Phase }|-|{ }^{131} \mid \text {-antiferritin antibodies in } \\
\text { hepatoma }\end{array}$ \\
\hline 1985 & Lenhard & $\begin{array}{l}{ }_{131}^{1} \text {-antiferritin } 15 / 38^{*} \text { respnses in } \\
\text { Hodgkin's }\end{array}$ \\
\hline 1985 & Order & $\begin{array}{l}{ }^{131} \text { I-antiferritin in } 105 \text { hepatoma } \\
\text { patients combined with external } \\
\text { RT and chemo; } 48 \% \text { response }\end{array}$ \\
\hline 1987 & Rosen & $\begin{array}{l}{ }^{131} \text { I-anti-CD5 2/6* PR in CTCL, } \\
\text { HAMA, thrombocytopenia }\end{array}$ \\
\hline 1987 & Epenetos & ${ }^{131}$ I-anti-HMFG, $9 / 24^{*}$ PR in ovary, IP \\
\hline 1988 & DeNardo & $\begin{array}{l}{ }^{131} \mathrm{I}-\mathrm{Lym}-1,3 / 5^{*} \text { response lymphoma } \\
\text { and CLL }\end{array}$ \\
\hline 1989 & Stewart & $\begin{array}{l}{ }^{90} \mathrm{Y} \text {-anti-HMFG, } 1 / 25^{*} \text { response in } \\
\text { ovary, myelosuppression }\end{array}$ \\
\hline 1989 & Press & $\begin{array}{l}{ }^{131} \text { l-anti-CD37, 4/4* response in } \\
\text { lymphoma }\end{array}$ \\
\hline 1990 & Schroff & ${ }^{186}$ Re-monoclonal antibody phase I \\
\hline 1990 & Brady & ${ }^{125}$-anti-EGFR in glioma \\
\hline
\end{tabular}

*Fractions represent responses (complete and partial) over number of patients treated. CLL Chronic lymphocytic leukemia; CTCL Cutaneous T cell lymphoma: EGFR Epidermal growth factor: HAMA Human antimouse antibodies; HMFG Human milkfat globulin; IP Intraperitoneal; PR Partial response; RT Radiotherapy

\section{TABLE 5}

Immunotoxins

\begin{tabular}{|c|c|c|}
\hline Year & First author & Results \\
\hline 1987 & Spitler & $\begin{array}{l}\text { Antimelanoma ricin A, } 1 / 22^{*} \text { in } \\
\text { phase I }\end{array}$ \\
\hline 1987 & Laurent & Anti-CD5 ricin A, 0/2* CLL \\
\hline 1988 & Hartler & Anti-CD5 ricin A, 0/4* CLL \\
\hline 1989 & Byers & Anticolon ricin $\mathrm{A}, 0 / 17^{*}$ in phase I \\
\hline 1989 & Spitler & $\begin{array}{l}\text { Antimelanoma ricin A, } 3 / 45^{*} \text { in } \\
\text { phase } \|\end{array}$ \\
\hline 1989 & Weiner & Antibreast ricin $\mathrm{A}, 0 / 4^{*}$ in phase I \\
\hline 1990 & Byers & $\begin{array}{l}\text { Anti-CD5 ricin A, } 16 / 32^{*} \text { response } \\
\text { GVHD in allogeneic transplant }\end{array}$ \\
\hline
\end{tabular}

"Fractions represent responses (complete and partial) over number of patients treated. CLL Chronic lymphocytic leukemia; GVHD Graft versus host disease

which inhibits protein synthesis, generally at the level of the $60 \mathrm{~S}$ ribosome. Most work has focused on the conjugation of the A-chain of ricin to monoclonal antibodies. In order to kill, these toxins must get inside cells. Such toxins are more cytotoxic than chemotherapy agents, but most toxins are much larger. For instance, ricin A-chain has a molecular weight of 32,000 Daltons. Also, natural toxins are antigenic themselves and induce a strong human immune response.

Clinical efforts with immunotoxins have been hampered by conjugation chemistry, large scale production issues and safety concerns. Results of some published trials are summarized in Table 5. HAMA, as well as antibodies against ricin A-chain, and a dose-limiting toxicity of a capillary leak syndrome manifested by normal liver function with hypoalbuminemia and edema have limited therapy. Some investigators have 
TABLE 6

\begin{tabular}{|c|c|c|}
\hline Year & First author & Results \\
\hline 1975 & Ghose & $\begin{array}{l}\text { Chlorambucil-antisera in } \\
\text { melanoma }\end{array}$ \\
\hline 1988 & Oldham & $\begin{array}{l}\text { Adriamycin-MoAb combinations, } \\
0 / 23^{*}\end{array}$ \\
\hline 1989 & Orr & $\begin{array}{l}\text { Mitomycin-C/MoAb combinations, } \\
0 / 19^{*}\end{array}$ \\
\hline 1989 & Schneck & $\begin{array}{l}\text { DAVLB-KS1/4, 0/13* adenoCA, } \\
\text { small bowel toxicity }\end{array}$ \\
\hline 1989 & Pietersz & N-Ac-Melphalan-MoAbs, $0 / 7^{*}$ \\
\hline 1990 & Elias & Methotrexate KS1/4, 1/6* \\
\hline
\end{tabular}

"Fractions represent responses (complete and partial) over number of patients treated. MOAb Monoclonal antibody

\begin{tabular}{|c|c|c|}
\hline Year & First author & Results \\
\hline 1988 & Weiner & $\begin{array}{l}\text { Gamma-IFN plus 17-1A in } \\
\text { colorectal cancer }\end{array}$ \\
\hline 1989 & Brown & $\begin{array}{l}\text { Alpha-IFN plus anti-idiotype MoAbs } \\
\text { in lymphoma }\end{array}$ \\
\hline 1990 & Caufield & $\begin{array}{l}\text { Alpha-IFN plus R24 anti-GD3 in } \\
\text { melanoma }\end{array}$ \\
\hline 1990 & Bajorin & IL-2 plus R24 anti GD3 in melanoma \\
\hline 1990 & Murry & $\begin{array}{l}\text { Alpha-IFN plus }{ }^{111} \text { In-antimelanoma } \\
\text { MoAb imaging }\end{array}$ \\
\hline
\end{tabular}

IFN Interferon; IL Interleukin: MoAb Monoclonal antibody

initiated trials with modified ricin A-chain immunotoxins and ricin preparations in which the nonspecific galactose binding site on the B-chain has been blocked. Chemical modification of the A-chain or use of recombinant A-chain may improve pharmacokinetics and decrease immunogenicity.

Chemoimmunoconjugates: If sufficient chemotherapy molecules could be delivered by monoclonal antibodies to tumour cells, greatly decreased toxicity and improved efficacy of chemotherapy would result. Cellular internalization of a drug attached to a monoclonal antibody decreases resistance to the agent, possibly by decreasing efflux of free drug (8). Through the years, investigators have explored conjugation of various agents. Many efforts were limited by inefficient yields, drug cross-linking, impaired immunoreactivity and limited specific cytotoxicity. More recently, attention has been directed to the use of linkers such as cisaconitate, glutaraldehyde, albumin and short amino acid sequences. These approaches are limited by the number of free amino groups, particularly on lysine residues. Sitespecific linkage to carbohydrate groups on the Fc portion of the Ig molecules may allow for attachment of additional drug for some antibodies. Some linker approaches neutralize the activity of the drug while it is linked, but activity is restored after acid hydrolysis

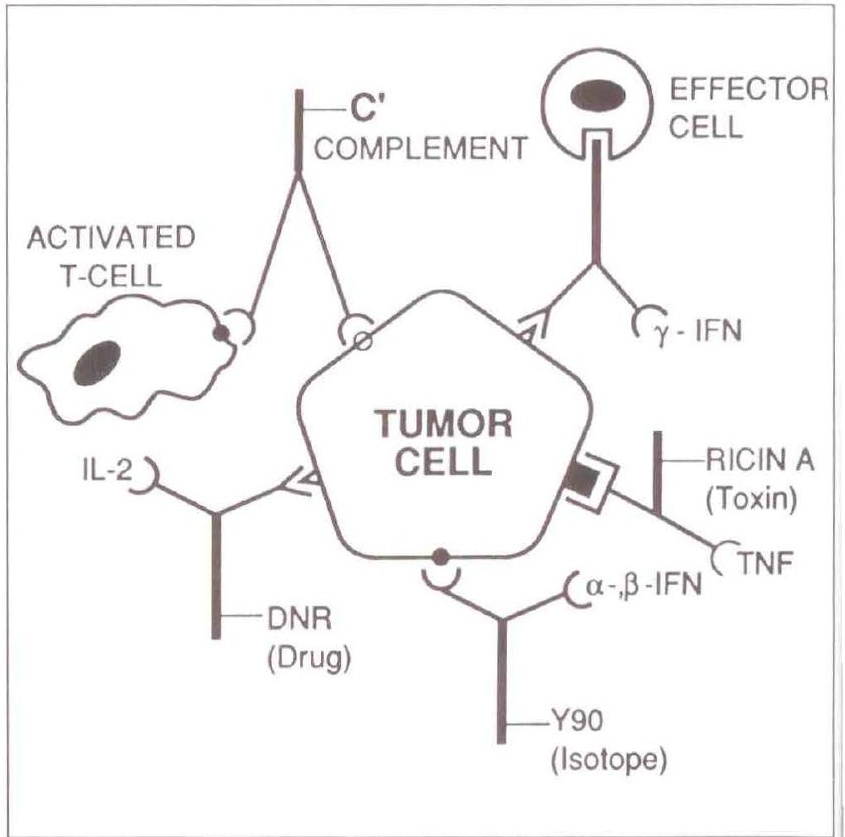

Figure 1) Potential combination monoclonal antibody therapy for cancer. Various antigens are depicted on the tumour cell surface representing the heterogeneity of cancer. Bifunctional antibodies are depicted with one Fab directed to a tumour antigen and the other to a biological response modifier (IFN Interferon, TNF Tumour necrosis factor, IL-2 Interleukin-2). One antibody has an Fab directed to a CD2 or CD3 receptor on $T$ cells which results in their activation and enhanced cytotoxicity. The Fc portions of the antibodies are attached to a variety of cytotoxic substances including complement, effector cells (granulocytes, monocytes, killer T cells) of the immune system and cytotoxic agents such as toxins, radioisotopes and chemotherapy agents (DNR Daunorubicin) (Reproduced with permission from reference 1)

inside the cell or in the relatively acidic environment around hypoxic tumour cells. Such conjugates can exhibit specific cytotoxicity and are as effective or more effective than equivalent amounts of free drug in vitro and are superior to drug alone or drug plus antibody in animal tumour models (8). There is only limited clinical experience with drug-immunoconjugates (Table 6). Chemistry and large scale production are persistent problems.

Cellular conjugates: Heteroconjugates or bifunctional monoclonal antibodies may be used to direct activated $\mathrm{T}$ cells to tumours. Monoclonal antibodies directed against the $\mathrm{T}$ cell receptors, $\mathrm{CD} 3$ or $\mathrm{CD} 2$, activate those cells into a cytotoxic state so that they will kill if they come in close contact with tumour cells, especially in the presence of interleukin-2. Anti-CD2 or anti-CD3 monoclonal antibodies can be chemically linked to monoclonal antibodies which react with tumour antigen to produce a heteroconjugate. Bifunctional monoclonal antibodies in which one arm of the molecule is bound to CD2 or CD3 and the other to a tumour-associated antigen can also be used. These approaches are promising in vitro. 


\section{MONOCLONAL ANTIBODIES WITH OTHER BIOLOGICAL RESPONSE MODIFIERS}

There is good rationale for using monoclonal antibodies in combination with other biological response modifiers. For instance, gamma-interferon increases the expression of $\mathrm{Fc}$ receptors on various effector cells and thus enhances ADCC. Interleukin-2 and tumour necrosis factor enhance cell-mediated cytotoxicity. Various interferons increase the expression of certain tumour-associated antigens. Vasoactive agents, such as interleukin-2, tumour necrosis factor or hyperthermia, may have vascular effects which allow more molecules to penetrate the tumour. Only a few pilot studies have been published (Table 7).

\section{ISSUES AND FUTURE DIRECTIONS}

The human anti-lg response is a major limitation for repeated therapy with murine monoclonal antibodies and appears to be an important consideration in the use of human and mouse-human chimeric monoclonal antibodies (9). An increasing number of clinical trials are being conducted with 'humanized' or human monoclonal antibodies. Depending upon the specific clinical goal, there are rationales for the use of antibody fragments rather than whole antibody. Similarly, there are some situations in which a heterofunctional antibody may be preferable to a monospecific bivalent antibody. Tumour cell heterogeneity is a major problem which may be overcome by using combinations of antibody. Monoclonal antibody immunoconjugates may offer the greatest opportunity to use combined modality therapy to overcome tumour heterogeneity (Figure 1).

ACKNOWLEDGEMENTS: This work was supported by the Patty \& George Hoag Cancer Center.

\section{REFERENCES}

1. Dillman RO. Monoclonal antibodies for treating cancer. Ann Intern Med 1989;111:592-603.

2. Kohler G, Milstein C. Continuous cultures of fused cells secreting antibody of predetermined specificity. Nature 1975;256:495-7.

3. Sikorska HM. Therapeutic applications of anti-idiotypic antibodies. J Biol Response Mod 1988;7:327-58.

4. Herlyn D, Ross AH, Koprowski H. Anti-idiotypic antibodies bear the internal image of a human tumour antigen. Science 1986;232:100-2.

5. Dillman RO, Beauregard JC, Jamieson M, et al. Toxicities associated with monoclonal antibody infusions in cancer patients. Mol Biother 1988; 1:81-5.

6. Goldenberg DM. Targeting of cancer with radiolabeled antibodies. Arch Pathol Lab Med 1988;112:580-7.

7. Pastan I, Willingham MC, FitzGerald DJB. Immunotoxins. Cell 1986;47:641-8.

8. Dillman RO, Johnson DE, Ogden JR, et al. Significance of antigen, drug and tumour cell targets in the preclinical evaluation of monoclonal antibody immunoconjugates. Mol Biother 1989;1:250-5.

9. Dillman RO. Human antimouse and antiglobulin responses to monoclonal antibodies. Antibody Immunoconj Radiopharm 1990;3:1-15. 


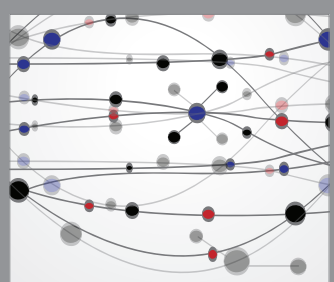

The Scientific World Journal
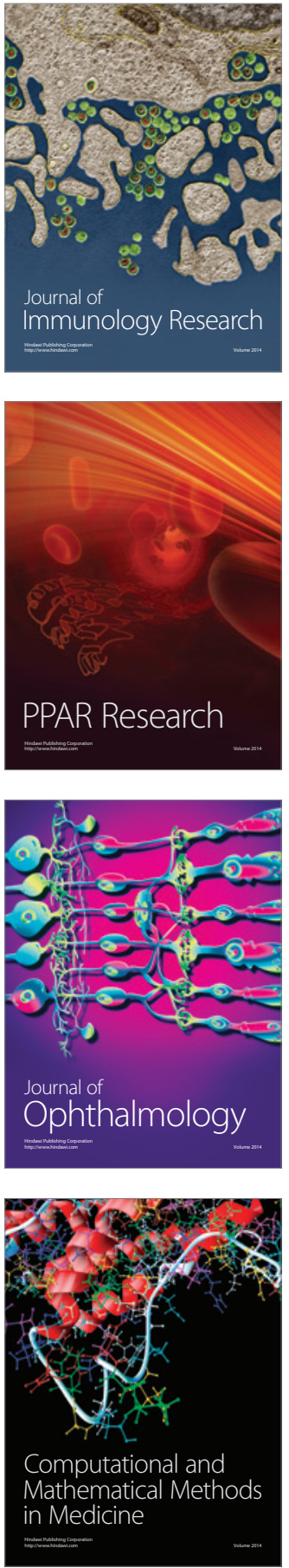

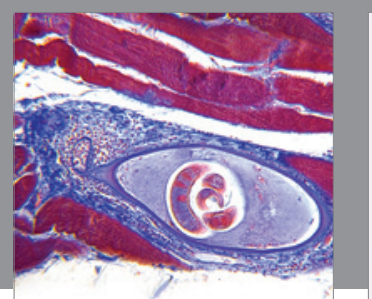

Gastroenterology Research and Practice

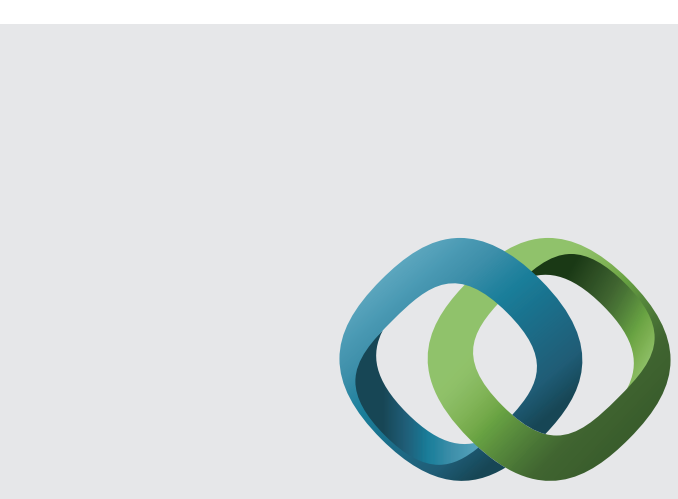

\section{Hindawi}

Submit your manuscripts at

http://www.hindawi.com
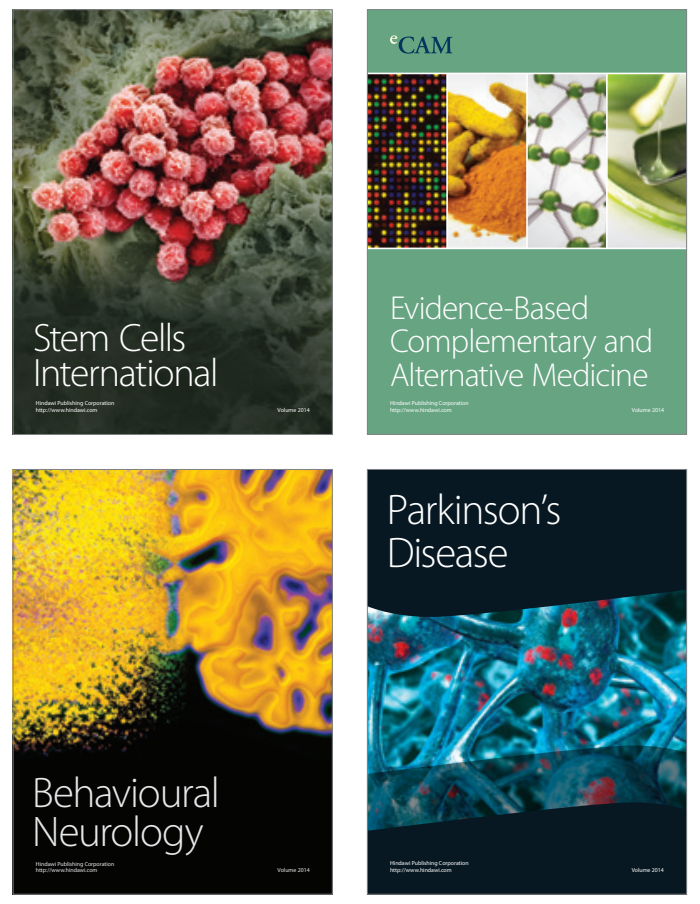
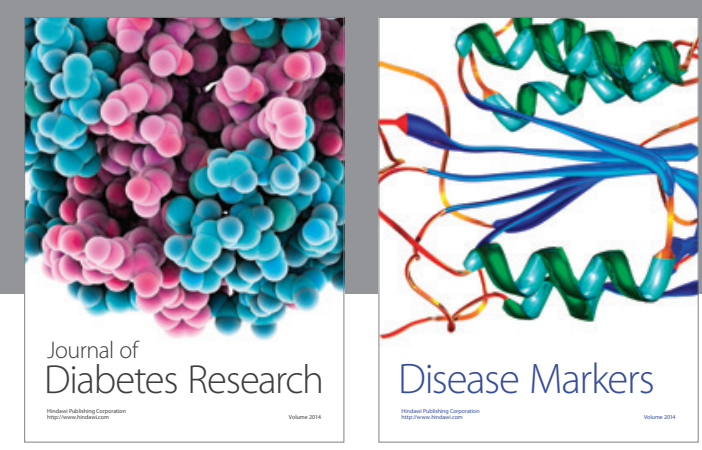

Disease Markers
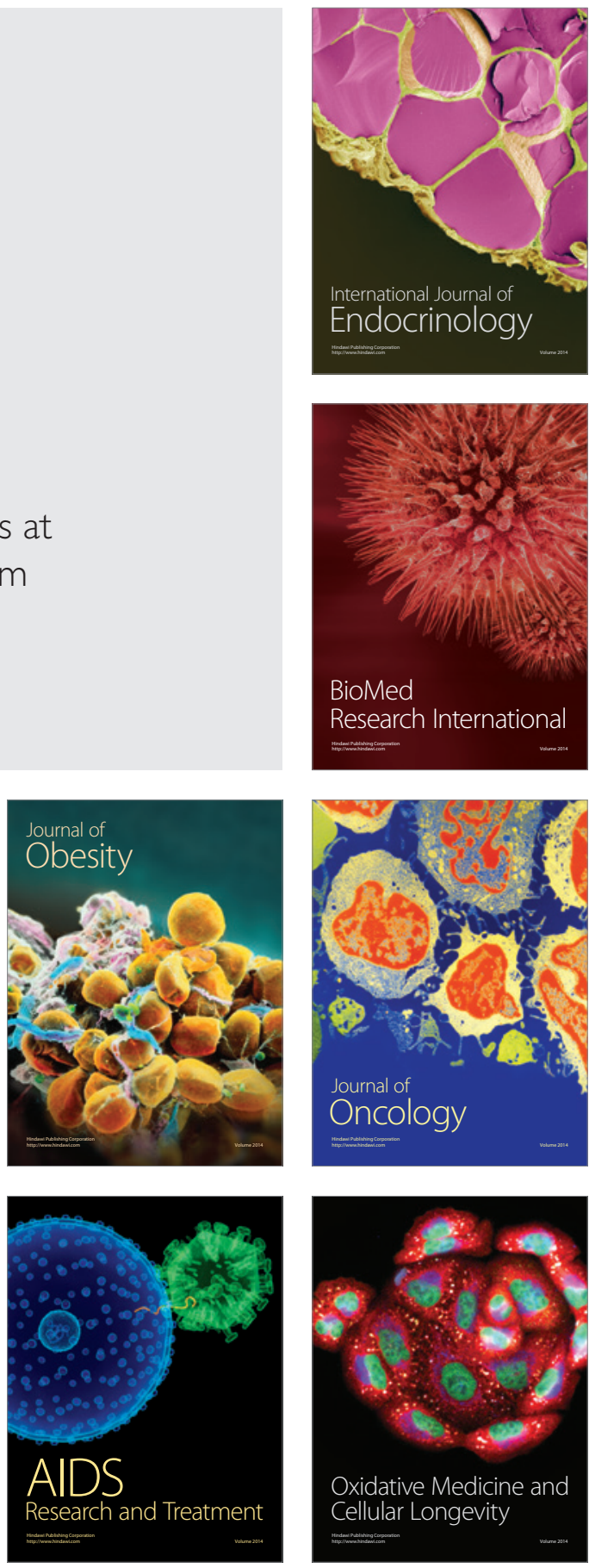